\title{
Marine, Maritime, or Submerged Prehistory? Contextualizing the Prehistoric Underwater Archaeologies of Inland, Coastal, and Offshore Environments
}

\author{
Jonathan Benjamin ${ }^{1,2}$ and Alex Hale ${ }^{3}$ \\ ${ }^{1}$ Wessex Archaeology, Coastal \& Marine, UK \\ ${ }^{2}$ University of Edinburgh, $U K$ \\ ${ }^{3}$ Royal Commission on the Ancient and Historical Monuments of Scotland, UK
}

\begin{abstract}
Studies in submerged prehistoric archaeology have gained momentum in recent years with particular focus on the inundated landscapes of the European continental shelf. Although this renewed interest lies primarily in modern coasts and seas, there are a variety of differences between the submerged prehistoric archaeologies of inland and marine environments, ranging from questions of scientific research to heritage management to practical field methods. Some of these differences are the result of location, function, and period. Despite this, there exist similarities that, if ignored, risk increased marginalization of the archaeology of submerged landscapes from the greater field of prehistoric archaeology. A holistic evaluation of prehistoric archaeological landscapes must include inland waters and coastal zones and their relationships. Aquatic environments, viewed both as individual locations as well as continuous and connecting waterways, are introduced for their differences and similarities, and simplified examples of material and legislation are introduced in order to contextualize submarine sites and practices within the greater fields of prehistory and underwater archaeology.
\end{abstract}

Keywords: underwater archaeology, coastal, lacustrine, riverine, estuarine, prehistory, Britain, Scotland

\section{INTRODUCTION}

It is clear that a holistic approach to prehistoric archaeology requires more than data and information from terrestrial environments. A truly 'seamless approach' to the study of the human past incorporates sites from the intertidal to the marine environment (Fulford et al., 1997; Tomalin, 2000; Miles, 2004) as well as sites from inland bodies of water. The differences as well as the similarities of coastal and inland sites, relevant to the topics of underwater archaeology and submerged prehistory, must be defined and included in the discourse of research, heritage management, and legislation.

The year 2009 was important for the study of Submerged Prehistory: the European Science Foundation, through the Cooperation in Science and Technology funded a network for developing the field of Submerged Prehistoric Landscapes and Archaeology on Europe's Continental Shelf (SPLASHCOS COST Action TD-0902) a 4-year programme to develop the emerging field. The same summer, a session at the 15th Annual Meeting of the European Association of Archaeologists (EAA) (Riva del Garda, Italy) titled Underwater 
archaeology and the future of submerged European prehistory, was organized by members of the archaeology department at the University of Edinburgh. The sixteen papers and additional posters presented during this full-day session ranged geographically from the North Atlantic to the Black Sea, inspired hearty discussion and were well attended by both underwater and terrestrial archaeologists. Topics included new sites and material, modelling of changing landscapes, migrations of prehistoric populations, remote sensing techniques, survey and excavation methodology, new site prospection, heritage management, research prioritization, legislation, as well as applications of paleoenvironmental and anthropological perspectives. The papers presented at the EAA meeting represented a substantial segment of the published volume Submerged Prehistory (Benjamin et al., 2011), which includes further research from around the world. The conference also presented an interesting question to the organizers: whether to include material from inland bodies of water, which were submitted for consideration. Although the focus of the session was designed to be on the European continental shelf, it was clear that there was interest from prehistorians working inland, and therefore lacustrine and riverine sites were included in the conference session (primarily as posters) and eventually, in the publication. This paper, without duplicating content, discusses the role of submerged prehistory within the greater field of archaeology, and extends this theme by comparing prehistoric coastal, marginal, and inland sites and practices, using examples from partially and fully submerged prehistoric archaeological sites.

What are the differences and similarities between coastal, estuarine, riverine, and lacustrine environments as they relate to the topic of submerged prehistoric archaeology? It could be argued that these differences are comparable with those of the terrestrial differences between upland, moorland, urban, continental, and island archaeologies. Furthermore, much like their terrestrial counterparts, the borders of these distinct environments can be blurred. They may connect, overlap, and/ or create a continuous waterway of cultural environments. Inland lakes may lead to rivers, which flow into estuaries, and on to the sea. Therefore, submerged archaeological evidence in these varied geographical locations should be viewed symbiotically as complementary to each other, to be examined by similar investigatory methodologies where applicable. Interpretations can be derived in one location, based on a particular set of circumstances and on a range of evidence, and, in some instances, may be appropriately applied to another location and set of archaeological remains. The results from this analysis and examination, combined with that from terrestrial sites, make up the record of a given prehistoric archaeological landscape.

The divergences, however, must be specifically identified, as too often the technical means for accessing underwater sites have defined the field of 'Underwater Archaeology'. We deliberately capitalize the term 'Underwater Archaeology' here to describe the field as a whole and recognize that others may prefer either the use of different terms, among them 'Marine Archaeology', and some have even included the study of submerged landscapes under a 'Maritime Archaeology' as a blanket term. Regarding this point, we refer to the foundations of the field proposed by Muckelroy (1978, Fig 1.1) and recognize the following definitions: (1) marine: of, in, near, concerned with, or belonging to, the sea and (2) maritime: pertaining to the sea relating to sea-going or sea-trade (Chambers, 2008).

This issue of terminology has recently been addressed by the Marine and 


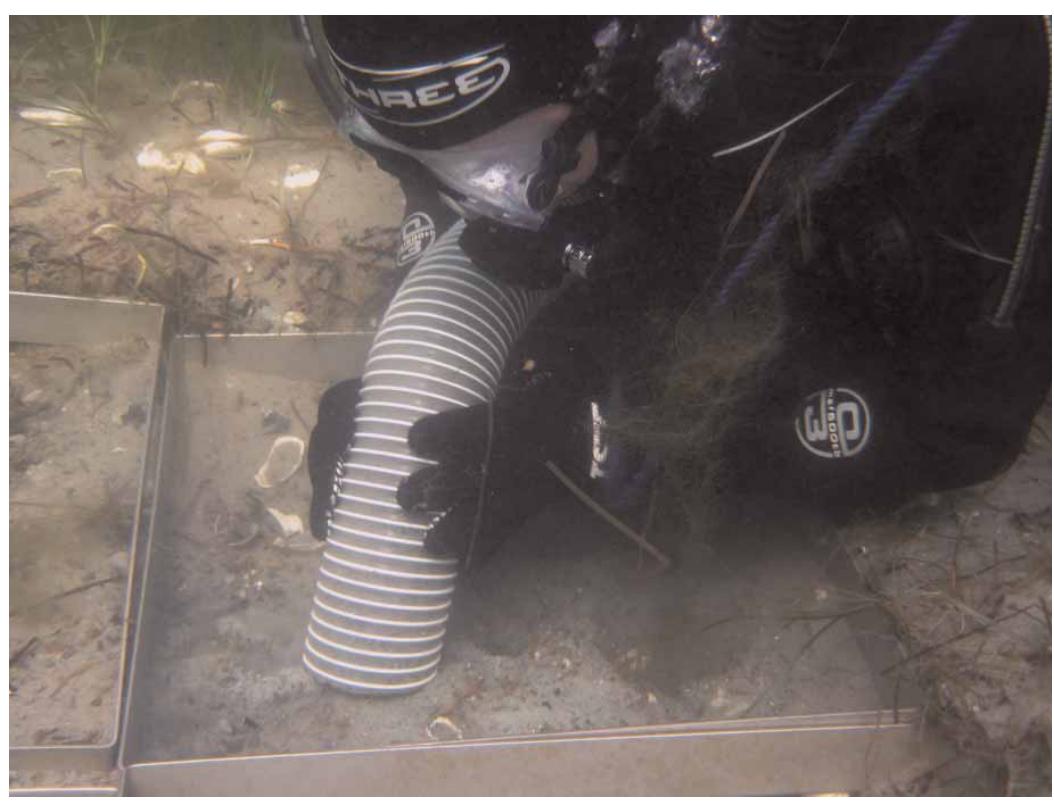

Figure 1. UK-based archaeologist John McCarthy excavates a test trench at a late Mesolithic site in the Danish Baltic.

(C) J. Benjamin.

Maritime panel for the Scottish Archaeological Research Framework (ScARF), when the matter of boundaries (i.e. where the remit of the panel would begin and end) was discussed (Atkinson \& Hale, 2012). It was decided that the sea formed a continuum with inland estuaries, which in turn could become riverine and potentially lacustrine. Hence, the panel adopted a 'source to sea' approach, which defined the marine and maritime archaeological environment as 'encapsulating the interrelationship of all aspects of human activity that ultimately link archaeological sites to the maritime zone'.

Historically, underwater archaeologists were considered a group because of the technical means used to access the underwater environment, particularly through SCUBA diving ( $c f$. Lenihan, 1983). That paradigm, however, is potentially dangerous because it can relegate the underwater archaeologist to the role of technician, rather than a qualified researcher or specialist. This attitude is fortunately disappearing with the various technical and theoretical approaches to underwater research and management, including the advancement and greater application of marine geophysics ( $c f$. Dix, 2007) and the conceptual developments and acceptance from the broader archaeological community regarding submerged landscapes $(c f$. Fischer, 1995; Flemming, 2004; Benjamin et al., 2011). Approaching this topic with an awareness of the contrasting differences between the archaeologies of marine and inland waters, we wish to explore the complementary elements of these differing resources and their associated field practices, by introducing a few brief examples from Britain and Ireland to demonstrate similarities and differences and to highlight overlap as well as separation in field practice, in order to promote the described 'seamless' consideration for prehistoric archaeology under water. This paper also discusses some of the broader 
issues to be considered when the concept of a potentially vast area of submerged landmass is introduced into the archaeological arena, as well as the importance of engaging a community of interest and the wider public, who potentially include fishermen, sport divers, and people who have local knowledge and an understanding of their natural and historic environment.

\section{Underwater Archaeologies}

As the greater prehistoric archaeological community may have historically underestimated underwater environments as a cultural resource, so too has the underwater archaeological community shown relatively limited interest in prehistoric, particularly 'Stone Age' archaeology (with some obvious exceptions: e.g. Masters \& Flemming, 1983; Fischer, 1995; Flemming, 2004; Benjamin et al., 2011). Apart from a few examples of Bronze and Iron Age sites in the Mediterranean (cf. Bass, 1972; Muckelroy, 1980; McGrail, 2001), shipwreck sites, which have dominated the field of Underwater Archaeology, are mainly Historic or Classical in age. Of the known underwater archaeological sites in the world, the vast majority is not prehistoric (Muckelroy, 1978; Delgado, 1997), and the study of submerged prehistory has thus remained on the fringes of Underwater Archaeology (cf. Muckelroy, 1978, Fig 1.1). An obvious example is found in The Encyclopedia of Underwater and Maritime Archaeology (Delgado, 1997: 6), which listed only fourteen entries classified as 'prehistoric archaeological sites'. These include broad-scale themes such as "lithic artefacts', 'prehistoric archaeology', 'Quaternary coastlines and land bridges', and 'shell middens'. Only three explicitly defined examples of European prehistory are represented: 'crannogs', 'Lake Neuchâtel', and 'Lake Zürich'. This limited prehistoric contribution stands in comparison with over three hundred examples of individual shipwrecks listed in the same section (Delgado, 1997: 6, 13). This point does not disparage the contributions of Maritime Archaeology (obviously an extremely important and relevant discipline in its own right), but rather illustrates the historical bias that has existed within Underwater Archaeology. Until recently, for many, the practice of Underwater Archaeology has been a technical component of maritime or nautical archaeology, with relatively little acknowledgement of the incredible potential of underwater research to significantly impact on our understanding of human prehistory. Thus, while in the past traditional archaeologists may have largely ignored underwater methodology, Underwater Archaeology has often dismissed submerged prehistory. It is encouraging that this has begun to permanently change.

There is a fundamental need to understand the types of sites that can be encountered by underwater archaeologists, and the potential methods for initial site discovery. Shipwrecks, maritime installations, and other large features may be identifiable by remote sensing techniques such as side scan sonar, multibeam bathymetry, or magnetometry (in the case of wrecks made of or containing metal). However, submerged prehistoric sites that are of a smaller, more ephemeral nature are unlikely to be encountered using these techniques alone (Figure 1). Sub-bottom profiler data may be interpreted to understand the physical setting and, in turn, yield palaeoenvironmental information. However, such survey methods are not likely to pick up individual, smaller-scale prehistoric deposits. Rather, these methods are useful in establishing potential, which would need to be tested by sampling, either by divers or other means ( $c f$. Lübke et al., 2011; Westley et al., 2011). Along with matters of site taphonomy and preservation, the 
archaeological signature, identifiable by remote sensing, is a major factor that contributes to the dominance of shipwrecks within Underwater Archaeology.

Underwater sites can be divided chronologically, but are probably more importantly distinguished by site taphonomy. There are four categories that have traditionally defined how an archaeological site can become submerged; a topic discussed since at least the 1950s (Goggin, 1960). (Goggin's description of site definition originally included 'discarded' and 'lost' material in a single category and 'shipwrecks' as its own separate category.) The four are: (1) Deposition or loss: This includes the sinking of a maritime vessel or the loss of an aircraft. (2) Submergence due to having been built on, in, or near water: This type of site would have been destroyed or deteriorated into the water and may include sites such as crannogs (artificial islands built in lochs in Scotland and loughs in Ireland, and used throughout prehistoric and later periods). (3) Votive or sacrificial sites: this category refers to sacrificial offerings, deliberately placed in the water and includes the Neolithic daggers found in Denmark (Fischer, 2004). They have also been referred to as 'shrine sites' in North America (Goggin, 1960). (4) Submerged terrestrial landsurfaces/ landscapes: This includes sites built or occupied on dry land, which were later inundated by rising water levels, tectonic subsidence, or a combination of these processes. A preserved archaeological landsurface represents a stratigraphic layer containing evidence of cultural occupation, whereas a cultural landscape is a conceptual term to refer to the occupation of a given area (cf. Bicket et al., 2012 for further discussion). Oxley (2007) includes the additional categories of remains related to coastal activities (such as munitions or rubbish, shot or dumped into the sea from shore) and subtidal elements of onshore coastal features as well as functional seabed emplacements (e.g. communication cables and pipelines that will become a part of the historic environment). These distinctions can, for the most part, be placed into the broad categories aforementioned. However, it is worth re-emphasizing Oxley's core message: submerged sites are complex in character and diverse in both type and age.

In describing the difference between prehistoric sites, there is a need to differentiate those sites located in coastal/ marine zones, specifically those inundated by eustatic sea-level rise, and those found in inland bodies of water. Although similar technological methods for survey and excavation may be applied within these different environments, lakes and rivers present different conditions of submergence and, therefore, the archaeological implications are often different to those of coastal sites. Underwater sites (and the field practices by the archaeologists who study them) may also be distinguished, based on the type of aquatic body in which it exists. River sites have been recently discussed for their own contributions and methodological challenges (e.g. Bonnamour, 2000; Szabó, 2000; Gaspari, 2003). Lacustrine sites possess unique conditions both for preservation as well as for excavation practice, and lake sites are historically significant for their contribution to underwater archaeological methodology (referenced in detail below), heritage management, and public awareness.

\section{Comparing INLAND ANd CoAstal Underwater Sites - AckNowledging the Differences and Similarities}

Broadly speaking, submerged coastal and inland sites offer different information on the prehistoric populations we study (illustrated by the examples below). The histories of science, existing research infrastructures, and public awareness are 
different. Although prehistoric intertidal sites in Britain have been observed since at least the 1830s (Boyd Dawkins, 1870) and the notion of Britain's prehistoric connection to mainland Europe by the late nineteenth century, Tomalin et al. (2011: 3) have noted the fact that Britain's scientific community acknowledged submerged landscapes 'indifferently' until the discovery of the Colinda point, which was trawled from the East Anglian coast, 25 miles from shore, in 1931. This indifference continued, except in 'pockets' through the late twentieth century. The activity from the Solent, as recently published by Momber et al. (2011), has shown the history of submerged prehistoric research in this particular region of southern England. Although chance discoveries (mainly by fishermen) were known since the 1960s, in situ site discovery and evaluation did not take place until 1999 (more on the Bouldnor Cliff sites below). To that end, archaeology on the continental shelf can still be considered as an emerging field within the greater archaeological community of Britain and indeed much of Europe. Compare this with prehistoric lake sites that have been acknowledged for nearly two centuries, and unlike their saltwater counterparts, have been the source of continuous research, discussion, and debate since their initial discovery. This is demonstrated by the increase in books published on crannogs over the past twenty years which builds on the previous decades of continuous study, debate, and publication that surrounded these sites since the nineteenth century ( $c f$. Mackinlay, 1859; Munro, 1882, 1905; Wood-Martin, 1886; Lang, 1905; O'Neill Henken \& Stelfox, 1942; Collins, 1955; Dixon, 1982, 2004; Coles, 1984; Morrison, 1985; O'Sullivan, 1998; Crone, 2000, 2007; Fredengren, 2002; Hale, 2004; Crone \& Campbell, 2005).

We should acknowledge some of the differences between inland (freshwater) prehistoric sites and their (saltwater) coastal counterparts. Site discovery is often different: methods of discovery of prehistoric lacustrine and marine sites can be vastly different due to visibility, depth, and site type. Underwater caves may prove to be a huge archaeological resource around the world and the prospection associated with such sites requires an entirely different approach than that of an underwater village in the Alpine Lakes (e.g. Arnold, 1990; Schlichtherle, 1997). They may address different research questions, particularly those of coastal resource exploitation, long-distance maritime transportation and early seafaring, and large-scale migrations (cf. Bailey, 2004; Erlandson \& Fitzpatrick, 2006); terrestrial sites, now under water due to global sea-level rise, present archaeologists with different types of information to interpret regarding subsistence economy, transportation, resource-exploitation, etc. (We note the potential for submerged prehistoric sites offshore to contain material that relates to early hinterland occupation as well as coastal sites, and cite the majority of currently known submerged prehistoric material to be from shallow, nearshore waters that represented prehistoric coastal occupation (with obvious exceptions; $c f$. Tizzard et al., 2011).) Site taphonomy, problems of erosion and site destruction vary, particularly when contrasting the variety of inland water types (from small standing lakes to large flowing rivers, etc.) or the different types and formations of coastlines. Finally, the scale of the bodies of water (and of potential research areas) differs vastly. Here, we are mainly considering the enormous surface area on the world's continental shelves that was available for prehistoric human occupation. Given the variety of site formation, preservation, and discovery processes, Oxley's assertion regarding complexity in underwater archaeological sites is valid even when 
excluding historical shipwrecks and other historic maritime sites.

Despite important conceptual and archaeological differences, prehistoric inland lake and river sites can provide complementary information to coastal archaeology. Applied methodologies and underwater archaeological fieldwork techniques may also overlap. At least six similarities between submerged prehistoric marine sites and underwater inland sites can be identified. They often boast excellent preservation of organic material in low-oxygen environments, which for many, is one of the greatest benefits of Underwater Archaeology. Archaeologists may require and employ similar technological means of access such as SCUBA diving, underwater documentation (photography/videography), remote sensing and remotely operated vehicles, etc. They require material identification in a nonterrestrial environment by archaeological divers, which is absolutely critical to conduct meaningful and efficient fieldwork under water. They may overlap temporally and provide archaeological data from contemporary periods, thereby enabling a fuller dataset and large-scale interpretations of the prehistoric cultural landscapes, waterways, and seascapes. Sites may provide complementary data on aquatic resource exploitation and waterborne-transportation, including the use of dugout boats and fishing methods; prehistoric fishing material from inland sites may be used to suggest contemporary methods of resource extraction (e.g. Köninger \& Lübke, 2001) or transportation (e.g. Fugazzola Delpino et al., 1993) in the coastal zone. Finally, legislation and heritage management may apply similar to coastal and inland bodies of water ( $c f$. UNESCO, 2001).

With respect to the initial discovery and the archaeological signatures of the lake sites referenced herein (e.g. crannog references listed above; and in Alpine Europe: e.g. Schlichtherle \& Wahlster, 1986; Arnold, 1990; Ruoff, 1997; Schlichtherle, 1997), a parallel can perhaps be drawn regarding the discussion relating to shipwrecks, primarily to do with the size of the identifiable feature. The prehistoric lacustrine sites refer mainly to larger features, such as crannogs or large areas where numerous pile-dwellings made up entire prehistoric settlements. It should be noted that smaller ephemeral sites and features, even thousands of years old, have been discovered in inland bodies of water and interpreted by skilled archaeologists ( $c f$. Gaspari, 2006; Leineweber et al., 2011).

\section{Legislation, Heritage Management, and Diving in Archaeology}

The point that legislation and heritage management may pertain similar to coastal and inland bodies of water is apparent in the UNESCO 2001 Convention on the Protection of the Underwater Cultural Heritage. This includes both the participation of land-locked nations, and the clause that any nation may apply the rules of the convention to their inland waters (in addition to their marine territories). Furthermore, due to the skill, experience, and equipment necessary to conduct underwater archaeological research, it is common throughout Europe that the same individuals, agencies, or research groups conduct fieldwork in both coastal and inland environments. The recent ScARF initiative in Scotland enabled both chronological and thematic, cross-cutting panels to develop research frameworks for their particular areas (e.g. see Atkinson, Hale \& Sanders, 2012). The Marine and Maritime panel has noted that the recent advance in Scottish law - the Marine (Scotland) Act, 2010, which enables Scottish Ministers to designate Historic Marine Protected Areas 
(HMPA) - to facilitate future management-led research in this area. These and similar advances of legislation worldwide, promote best-practice and realworld solutions to improve our understanding and promote better management of the underwater heritage.

As management of coastal resources, such as minerals, aggregates (sand and gravel), and energy (fossil fuel and renewables) grows to meet societal and economic demands, sustainable development requires a greater understanding of the historic environment through regional and development-specific environmental assessment (cf. Firth, 2000, 2004). Archaeologists work alongside marine industry more than ever and the tools and methods that are established have enabled underwater archaeologists to progress technologically. This ever-growing relationship between responsible development and marine archaeology will result in the overall progression for survey and excavation techniques in marine and fresh water environments alike. As remote sensing, recording methods, and prospection techniques continue to develop, new sites will be recorded by archaeological divers and managed appropriately. Recent emphasis on Managing the Marine Cultural Heritage (Satchell \& Palma, 2007, which refers specifically to saltwater environments) shows that there is scope for the expansion of content to include inland sites that are preserved under water. Acknowledging the similarities and differences will promote the transferability of these technical, conceptual, and practical advances.

It has become an adage that it is easier to teach an archaeologist to dive than it is to teach a diver to become an archaeologist. However, it is worth considering that diving requires a specialized set of physical and mental abilities and experience, and working in the underwater environment can be difficult, particularly regarding material identification. Owing to differing conditions of preservation, such as artefact discoloration, decay, patination, etc., cultural material can be difficult to distinguish under water. Furthermore, underwater sediments, natural deposits (e.g. flint in natural moraine deposits), accumulations of shells, vegetation, or other naturally occurring aquatic life, may be difficult to identify and may confuse the inexperienced terrestrial archaeologist learning to work under water. Such variations of naturally occurring material are present in both marine and freshwater environments. A diver's ability to access, and effectively interpret, an underwater site is crucial; just as an untrained diver may not know how to interpret archaeological material, a non-diving archaeologist may have difficulty in filtering out the unfamiliar 'noise' of the underwater environment, be it freshwater, brackish, or marine.

\section{Demonstrating Context through VARIATIONS}

The following examples are introduced in order to help provide a context for differing types of (partially or fully) submerged sites and underwater archaeologies by identifying similarities and differences. These short case studies are intended to quickly demonstrate key points and highlight some of the practical experience in the field (but are not intended to be comprehensive discussions or detailed historiographical descriptions of the sites).

\section{Coastal}

Bouldnor Cliff is, to date, the only confirmed fully submerged prehistoric site to be excavated and interpreted by archaeological divers in the United Kingdom (Momber, 2000; Momber et al., 
2011). The Mesolithic site emerged following years of local observations of submerged palaeoenvironmental markers, and stone tools recovered from the seabed by fishermen. The site (or rather locality containing the multiple Bouldnor Cliff sites) began with assessments including 'underwater field-walking' by divers (Tomalin et al., 2011). This informed and partly defined a management strategy for submerged archaeology in the Solent and along the south coast of England (Tomalin, 1991). The Bouldnor Cliff sites were recently described in detail by Momber et al. (2011) and come from an exposed peat terrace submerged at a depth of $11 \mathrm{~m}$ (Momber et al., 2011, Fig 1.9). The submerged and eroding paleolandsurface is laterally extensive, running to over 1 $\mathrm{km}$ in length. Lithic scatters were found among the timber remains, which were dated to c. 6350-6570 cal BC (Tomalin et al., 2011).

This work provides the following points for its symbiotic nature to archaeology in its wider context. The initial questions of palaeoenvironmental development were addressed by the specialists of a broader research group, who continued to research, in parallel with their archaeological counterparts. Thus, relevant specialists provided not only necessary datasets and environmental context for the development of Bouldnor Cliff itself, but placed it within its wider context of the development of the Solent river system (Long \& Tooley, 1995). The sites provided anthropogenic evidence for the occupation of a submerged land surface, which, given the presence of associated cultural material, must have been exposed for some time and provides a sealevel index point for the Mesolithic period, for this part of southern Britain. Finally, the survival, condition, and recovery methods of the remains discovered at Bouldnor Cliff continue to help define some of the taphonomic processes that should be considered during investigation and interpretation. The excavators, The Hampshire and Wight Trust for Maritime Archaeology (HWTMA) have also helped to establish practical field methods for the recovery and analysis of material from a difficult working environment, plagued by poor visibility and strong tidal currents (Momber et al., 2011).

\section{Estuarine}

The Rising Tide: Archaeology and Coastal Landscapes (Aberg \& Lewis, 2000) demonstrates the Nautical Archaeology Society's deliberate engagement with landscape studies; there is a notable focus on the theme of the maritime landscapes and archaeology in transitional zones (that includes prehistory). The estuary is a very important component of the 'seamless approach' and archaeological assessment for all periods (and we note the decision to use a tidally influenced estuary by Aberg and Lewis for their book's cover image). Estuaries are especially important for prehistoric settlement and marine resource exploitation and will continue to play an important role in northern European archaeology; this refers to modern geography as well as palaeo-estuarine environments that are now submerged (cf. Fischer, 1995; Larsson, 2004 and the discussion section of that volume). However, for the purposes of this discussion, perhaps the more extensive and intensively researched example of estuarine archaeology in the United Kingdom comes from the Severn.

Over the last 25 years, there has been an extensive and intensive programme of research focused on the Severn Estuary, which acts as a natural border between Wales and southwest England (cf. Bell, 1992; Bell et al., 2000). One area in 
particular has been rich in Mesolithic archaeology, situated in the intertidal zone at Goldcliff East (Bell, 2007). The sites range from submerged forest remains, lithic scatters, peat deposits, other palaeoenvironmental deposits such as insects, pollen and plant macrofossils, and, perhaps most striking, the prehistoric footprints of humans and animals. Dating the submerged forests and five of the archaeological sites range between 6340 and 3790 cal BC, placing them within the Mesolithic period for southwest Britain (Nayling \& Manning, 2007).

The following points should be recognized when considering these sites for their contextual contribution. The methods applied and developed over 25 years of research provide current and future researchers with a handbook of techniques to engage with intertidal archaeological and paleaoenvironmental remains. Subsequent and concurrent researchers in Ireland and Scotland have benefited from the technological advances developed in the Severn Estuary (cf. O’Sullivan, 2001; Hale, 2004; Hale \& Sands, 2005). Furthermore, the presence of organic remains at the Goldcliff East sites, despite aggressive estuarine, erosive conditions, informs both local and regional reconstructions of the contemporary palaeoenvironment, human occupation, and resource exploitation. Bell (2007) has illustrated their major implications for interpretations of the Mesolithic and Early Neolithic across Wales and the south west of England.

\section{Riverine}

Sites located in riverine environments provide useful comparisons, of both similarities and differences to the (now marine) submerged prehistory of terrestrial landscapes. Although the archaeological record of Britain's rivers lacks substantial account of early prehistoric material, an example of site type from the British Bronze Age may provide an appropriate parallel and demonstrate a possible crosstemporal application for the interpretation of archaeological datasets.

The study of metalwork deposition from Northern Europe (cf. Bradley, 1979, 1998) provides a suitable comparison for some earlier submerged prehistoric discoveries where finds were initially thought to be accidental losses. On re-evaluation, however, these deposits were recognized as acts of various forms of particular depositional rites. Deposited metalwork appears in the archaeological record during a certain period and in a variety of terrestrial and watery contexts. The distinct class of deposit found in rivers is demonstrated by the quantity of objects found across Northern Europe (exemplified by the tens of tons of prehistoric metalwork found in the River Thames, England; cf. Bradley, 1998) and the good condition of many of the objects indicates a deliberate act, rather than mundane disposal.

The theories behind the acts of deposition have been rehearsed extensively elsewhere (Needham, 1988; Bradley, 1998; York, 2002). It is debatable whether the depth and complexity of the interpretation of votive sites from later prehistory can be applied to lithic caches in submerged prehistoric landscapes, given the current paucity of evidence. However, a jadeite Neolithic axe found associated with the Somerset trackways is a glimpse of the possibility of earlier votive finds from Britain (Coles \& Coles, 1988; see also Cassen et al., 2011 for an example from Northern France). Fischer (2004) has demonstrated the range of types of sites around the coast of Denmark and identified the differences between sacrificial sites and stray finds for Neolithic and later material. The locations of sacrificial sites around Denmark's coast are closely aligned with 
present shorelines in the fjords and narrow straits, whereas stray finds occur across all of these environments. With the increasing number of finds from submerged landscapes across Europe, relevant approaches for the interpretation of some of these sites may have already been developed by researchers who have focused on later prehistory.

\section{Lacustrine}

Examples of lacustrine archaeology are perhaps the best comparanda for the marine environment and submerged prehistoric landscapes. Examples of crannogs from Scotland and Ireland provide large datasets and a rich history of methods of investigation, survival of organic and inorganic remains, and the ability of their interpretations to be used in the wider field of archaeological discourse. Scottish crannogs range in date from the Neolithic to the Late Medieval, although it has been recognized that there were both flourits and hiatuses of crannog building and occupation activity (Henderson, 1998). Radiocarbon dating of Scottish crannog sites has demonstrated two specific peaks, centred around the later part of the first millennium $\mathrm{BC}$ and the start of the first millennium $\mathrm{AD}$, and the second period of activity between AD 500 and 800 (Crone, 1993).

One earlier example, a Neolithic lacustrine site at Eilean Domhnuill, North Uist, Outer Hebrides is dramatically earlier in date than most of the loch settlement sites in Scotland (Armit, 1992). The site was dated typologically, primarily by the ceramic assemblage of some 20,000 sherds, and by radiocarbon determination, which included a single grain of barley from a hearth that yielded a date between 3350 and $3550 \mathrm{cal} \mathrm{BC}$. There are questions of classification of this prehistoric lacustrine site, but given the development of different models of crannog types ( $c$.
Barber et al., 2007 for further examples of lacustrine settlement), we should consider that this site could indeed be classed within the 'crannog' spectrum. However, we take a cautious approach, appreciating the complexity and acknowledging the varying loch levels and environmental change. It may have been originally built on a promontory, or the shore of the loch.

Although crannog sites are typically dated to the peak periods (the Iron Age and Medieval), there are at least five known lake sites in Scotland's Outer Hebrides that are either categorized as Neolithic or have yielded confirmed Neolithic material according to the Western Isles Historic Environment Record (D. Anderson, personal communication; Figure 2). This further raises the question of the type of lacustrine sites, their use, taphonomy, and location of settlements during the Neolithic (as compared with later prehistory) and regionally, in the west of Scotland and the Hebrides. Further investigation of these lacustrine sites may yield more definitive answers to their status as crannogs, and their original function (i.e. settlement versus ceremonial usage) as well as the likelihood of reuse in later periods.

It can be said that crannog studies, as an established specialization, has perhaps maintained an unhealthy distance from the broader archaeological discourse, possibly leading to a type of ghettoization: a sub-field ostracized from the mainstream a phenomenon noted in the field of wetland archaeology (Van de Noort \& O' Sullivan, 2006). This leads to an information lag from the sub-discipline into the mainstream of archaeological practice and theory. As a result, the information discovered in crannog studies has not been appropriately integrated into the wider archaeological discourse. Although crannog studies have produced a large dataset (or datasets) of information, 


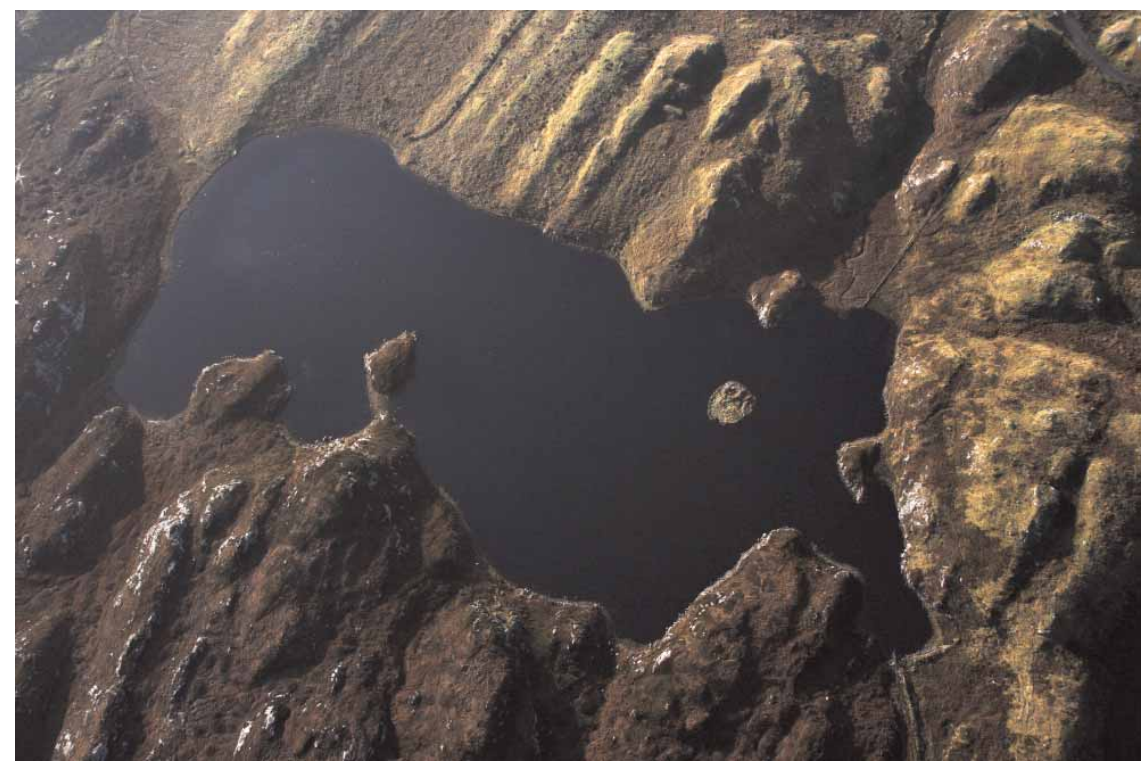

Figure 2. In 2011, a local diver discovered submerged early Neolithic material in Loch Duna, Lewis, Scotland.

(C) J. Benjamin.

most work has focused on individual sites, rather than the overall archaeological landscape.

\section{Discussion}

\section{Size matters}

We can identify large-scale archaeological objects within the intertidal zone, in shallow freshwater environments, through observation from shore, aerial photographic survey (cf. Harding, 2007), and even satellite imagery. In addition, models have been developed, so that prospective survey for finding new sites can be tested (Hale, 2007). However, these approaches rely on the scale of the features or sites to be readily identifiable such as a crannog, or, for the fortunate archaeologist, a logboat (cf. Mowat, 1996). But it is at the smaller end of the scale of objects that issues arise and this is perhaps where the search for clues towards the identification of submerged and in situ palaeolandsurfaces or landscapes has come into play. This question of visibility, is one of the important factors why historically, intertidal, and submerged forests (and peats) have been sought in order to identify early prehistoric deposits where cultural material is likely to be discovered in situ.

The issue of scale and archaeological signature is one that refers to all periods of Underwater Archaeology, and is not unique to the subset of prehistoric sites. Indeed, as discussed earlier, there is no clearer reason than the ability for positive identification that Underwater Archaeology and the record in marine historic environments worldwide have been dramatically skewed towards large shipwrecks. In Scotland, this bias towards large, metal shipwrecks has been noted (Historic Scotland, 2009) and special attention has been focused on identifying other categories of maritime and submerged prehistoric sites. Hence, we see a correlation between the size of a site and the 
types of techniques applied in order to locate them. As management of the seabed becomes increasingly relevant on local, national, and international agendas (as is the current case for Scotland, the United Kingdom, and the European Union), techniques in marine survey and Underwater Archaeology will need to re-focus and fine-tune to ensure that the smaller sites are considered and accounted for appropriately in an attempt to move beyond acknowledging purely their potential to exist in situ.

\section{The importance of the 'community'}

The heritage sector is acutely aware that knowledge transfer and engagement with people outwith the professional community is vital for furthering our understanding of the past ( $c f$. Thomas, 2010). Recent shifts towards community participation have taken hold across the heritage sector, which are designed to enable people to participate, share information, and learn skills from experts ( $c f$. DCMS, 2010; RCAHMS, 2011). This enablement ethos includes the potential for sport divers and fishermen to report and share information about archaeological finds from freshwater, estuarine, and marine environments. This approach broadens the knowledge network significantly and is designed to help both the public and researchers to gather greater information about our shared past. Additionally, it further validates the professional heritage sector, and its members, as an irreplaceable component. Part of the UK government's 'Big Society' approach is designed to enable people to take part in particular events, by giving their time and skills. This approach, albeit not new, can be applied to the virtuous cycle of knowledge transfer between experts, who can raise awareness of the issues and potential of the submerged prehistory (and who share their skills freely), and participants, who in this case have local knowledge of submerged findspots, the location of obstructions, understanding of shoreline changes, and other vital information.

Engagement on a close, sustained level enables people to share knowledge and exchange ideas; for example, if public participants see a real and lasting benefit for them and their community they are more likely to take part in or contribute to a project (Geddes \& Hale, 2010). If the project timing is sustained it builds the relationships within the project group and this can have lasting benefits for the knowledge-sharing cycle - in this case local divers and fishermen sharing information about submerged archaeology (Figure 3). However, divers and fishermen are not the only community groups who contribute to the discovery of submerged archaeological sites. The largest group of initial discoveries, during the 1980s - the heyday for submerged prehistoric site discovery in Denmark - was from the local community of residents, beach-walkers and swimmers, etc., who found indications of sites washed up on shore, or in the shallow waters and intertidal zones (Smed, 1987). Of the seven hundred sites cited by Smed, just under one-quarter were discovered by divers and fishermen (combined), whereas nearly half of the sites were discovered by 'local amateurs'. This figure may now need to be updated given that, since this initial publication, the number of finds in Denmark has increased considerably (Fischer, 2011). However, the data and its analysis remain telling: it reflects the importance of the local community, particularly when investigating new locations where the history of investigation may be in its infancy (Benjamin, 2010).

Education programmes are one way to embed the knowledge cycle and this can take 


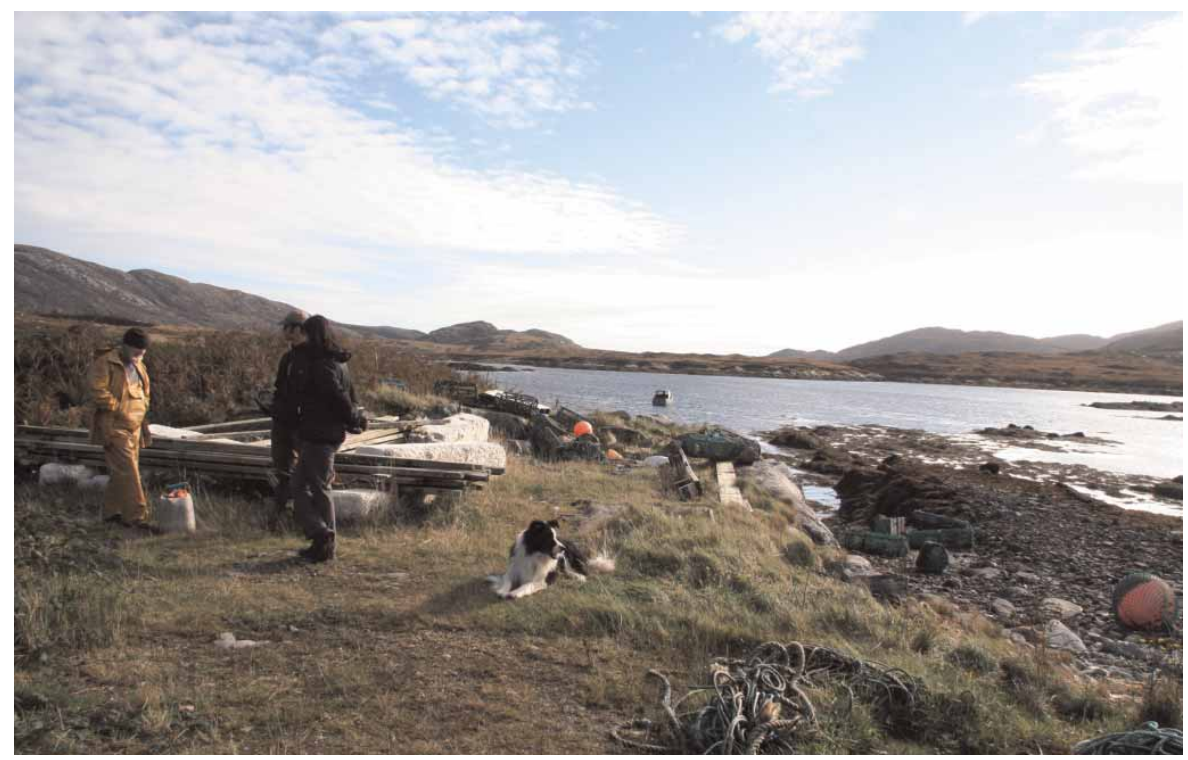

Figure 3. Public engagement and community outreach has led to the discovery of numerous underwater prehistoric sites throughout Europe. Although shipwrecks may be the most intuitive and obvious example that people associate with underwater archaeology, community engagement is important for understanding local environments, preservation potential and for sharing information about chance finds (which can, in turn, lead to the discovery of in situ deposits).

(C) J. Benjamin.

place on a variety of scales, from national to regional and local. On a national scale, education is best serviced through primary, secondary, and tertiary education strategies for example, using aspects of the National Curriculum to introduce the notion of a submerged past around the British Isles and Europe. On a local scale, infrastructure such as heritage societies, local museums, and civic trusts can provide suitable programmes for local lectures, workshops, and information sharing sessions.

In terms of raising awareness, multimedia approaches are necessary in today's connected world (Weirich, 2007). This ranges from traditional print media strategies to social media websites being established and, importantly, maintained over the course of a project and beyond. This issue of project legacy should be addressed early on, in project planning, to enable project participants to be involved so that their expectations are understood and accounted for, post-project.

\section{Concluding Remarks}

In an effort to identify the differences, similarities, relationships, and significance of prehistoric underwater archaeology (or archaeolgies), we hope to have made a few key points that provide context for the study of prehistory in differing aquatic environments by highlighting practical and organizational elements within the current state of the field. A symbiotic, albeit simplified, nature of different types of submerged prehistory has been introduced and the examples demonstrate, contextualize, and compare inland, estuarine and intertidal sites with fully submerged sites now on the continental shelf. The importance of inclusion of this sub-field to be integrated into the broader archaeological 
discourse has been noted and we emphasize the need for greater camaraderie, awareness, and indeed symbiosis within archaeologies underwater (and those who practice them). Training in identification and managing prehistoric material within underwater archaeological communities, academic institutions, and the general public is equally important. Without a conscious effort to broaden academic and public awareness, prehistoric cultural material may go unnoticed by divers - even by marine archaeologists unprepared for its potential presence. We anticipate that the current, developing, pan-European programmes of research, and education (e.g. SPLASHCOS (COST Action TD-0902), the North Sea Research Framework, ScARF, etc.) will translate directly into more significant underwater archaeological discoveries; particularly as submerged prehistory becomes more established among underwater archaeological circles, prehistorians, and importantly - the general public.

\section{Acknowledgements}

The authors would like to thank the numerous underwater archaeologists, particularly those field practitioners, whose work has inspired thought, discussion, and debate and has brought to life the cultural resource of their respective submerged environments. Thanks to Prof. Clive Bonsall and the unnamed reviewers for their very helpful comments on earlier drafts of this paper. Thanks are extended to Deborah Anderson, CNE Siar Regional Archaeologist, for her information relating to the Western Isles Historic Environment Record.

\section{REFERENCES}

Aberg, A. \& Lewis, C. eds. 2000. The Rising Tide: Archaeology and Coastal Landscapes. Oxford: Oxbow.
Armit, I. 1992. The Hebridean Neolithic. In: N. Sharples \& A. Sheridan, eds. Vessels for the Ancestors. Edinburgh: Edinburgh University Press, pp. 307-21.

Arnold, B. 1990. Cortaillod-Est et les villages du lac de Neuchâtel au Bronze final. Structure de l'babitat et proto-urbanisme. Archaeologie Neuchâteloise 6. Saint-Blaise, Switzerland.

Atkinson, D. \& Hale, A. eds. 2012 (in press). A Marine \& Maritime Scottish Archaeological Research Framework. Edinburgh: Society of Antiquaries of Scotland. Online Publication.

Atkinson, D., Hale, A. \& Sanders, J. eds. 2012. From Source to Sea: A Marine E Maritime Scottish Archaeological Research Framework. Edinburgh: Society of Antiquaries of Scotland, Online Publication.

Bailey, G. 2004. The Wider Significance of Submerged Archaeological Sites and their Relevance to World Prehistory. In: N.C. Flemming, ed. Submarine Prebistoric Archaeology of the North Sea. Research Priorities and Collaboration with Industry. CBA Research Report 141. York: Council for British Archaeology, pp. 3-10.

Barber, J., Clarke, C., Crone, A., Hale, A., Henderson, J., Housley, R., Sands, R. \& Sheridan, A. eds. 2007. Archaeology from the Wetlands: Proceedings of the 11th WARP Conference, Edinburgh 2005. Edinburgh: Society of Antiquaries of Scotland.

Bass, G. 1972. A History of Seafaring Based on Underwater Archaeology. London: Thames \& Hudson.

Bell, M. ed. 1992. Severn Estuary Levels Research Committee, Annual Report 1992. Aberystwyth: Severn Estuary Levels Research Committee.

Bell, M. 2007. Prehistoric Coastal Communities: The Mesolithic in Western Britain. CBA Research Report 149. York: Council for British Archaeology.

Bell, M., Caseldine, A. \& Neumann, H. 2000. Prehistoric Intertidal Archaeology in the Welsh Severn Estuary. CBA Research Report 120. York: Council for British Archaeology.

Benjamin, J. 2010. Submerged Prehistoric Landscapes and Underwater Site Discovery: Reevaluating the 'Danish Model' for International Practice. Journal of Island and Coastal Archaeology, 5(2): 253-73. 
Benjamin, J., Bonsall, C., Pickard, C. \& Fischer, A. eds. 2011. Submerged Prebistory. Oxford: Oxbow.

Bicket, A., Tizzard, L., Firth, A. \& Benjamin, J. 2012 (in press). Heritage Management and Submerged Prehistory in the United Kingdom. In: J. Flatman, E. Evans \& N. C. Flemming, eds. Submerged Prebistoric Archaeology: How Climate Change and Technology are Rewriting History. New York: Springer.

Bonnamour, L. 2000. Archéologie des Fleuves et des Rivières. Paris: Errance \& Ville de Chalon-sur-Saone.

Boyd Dawkins, W. 1870. On the Discovery of Flint and Chert under a Submerged Forest in West Somerset. Journal of Ethnological Society of London, 2(2): 141-46.

Bradley, R. 1979. The Interpretation of Later Bronze Age Metalwork from British Rivers. International Journal of Nautical Archaeology, 8: 3-6.

Bradley, R. 1998. The Passage of Arms: Archaeological Analysis of Prehistoric Hoards and Votive Deposits. Oxford: Oxbow.

Cassen, S., Baltzer, A., Lorin, A., Fournie, J. \& Sellier, D. 2011. Submarine Neolithic Stone Rows Near Carnac (Morbihan), France: Preliminary Results from Acoustic and Underwater Survey. In: J. Benjamin, C. Bonsall, C. Pickard \& A. Fischer, eds. Submerged Prehistory. Oxford: Oxbow, pp. 99-110.

Chambers. 2008. The Chambers Dictionary. Edinburgh: Chambers.

Coles, J. 1984. The Archaeology of Wetlands. Edinburgh: Edinburgh University Press.

Coles, J. \& Coles, B. 1988. Sweet Track to Glastonbury: Somerset Levels in Prehistory. London: Thames and Hudson.

Collins, A.E.P. 1955. Excavations in Lough Faughnan Crannog, Co. Down, 1951-1952. Ulster Journal of Archaeology, 18: 48-82.

Crone, B.A. 1993. Crannogs and Chronologies. Proceedings of the Society of Antiquaries of Scotland, 123: 245-54.

Crone, A. 2000. The History of a Scottish Lowland Crannog: Excavations at Buiston, Ayrshire 1989-90. STAR Monograph 4. Edinburgh: Scottish Trust for Archaeological Research.

Crone, A. 2007. From Indirections Find Directions Out: Taphonomic Problems at Loch Glashan Crannog, Argyll. In: J. Barber, C. Clark, M. Cressey,
A. Crone, A. Hale, J. Henderson, R. Housley, R. Sands \& A. Sheridan, eds. Archaeology from the Wetlands: Recent Perspectives. Proceedings of the 11th WARP Conference, Edinburgh 2005. WARP Occasional Paper 18. Edinburgh: Society of Antiquaires of Scotland, pp. 223-30.

Crone, A. \& Campbell, E. 2005. A Crannog of the 1st Millennium AD. Edinburgh: Society of Antiquaries of Scotland.

DCMS. 2010. Taking Part - Statistical Release. Taking Part: The National Survey of Culture, Leisure and Sport, Adult and Child Report 2009 [online]. London: Department of Culture, Media and Sport [accessed 17 May 2011]. Available at: <http://www.dcms.gov.uk/ images/research/ Taking_Part_Y6_Q3_JanDec10.pdf>

Delgado, J.P. 1997. The Encyclopedia of Underwater and Maritime Archaeology. London: British Museum Press.

Dix, J. 2007. Acoustic Characterisation of Archaeological Materials in the Marine Environment: Developments and Challenges. In: J. Satchell \& P. Palma, eds. Managing the Marine Cultural Heritage: Defining, Accessing and Managing the Resource. CBA Research Report 153. York: Council for British Archaeology, pp. 17-24.

Dixon, T.N. 1982. A Survey of Crannogs in Loch Tay. Proceedings of the Society of Antiquaries of Scotland, 112: 17-38.

Dixon, T.N. 2004. The Crannogs of Scotland: An Underwater Archaeology. Stroud: Tempus.

Erlandson, J. \& Fitzpatrick, S. 2006. Oceans, Islands, and Coasts: Current Perspectives on the Role of the Sea in Human Prehistory. Journal of Island and Coastal Archaeology, 1(1): 5-32.

Firth, A. 2000. Development-Led Archaeology in Coastal Environments: Investigations at Queenborough, Motney Hill and Gravesend in Kent, UK. In: K. Pye \& J. Allen, eds. Coastal and Estuarine Environments: Sedimentology, Geomorphology and Geoarchaeology. Geological Society Special Publications 175. London: Geological Society, pp. 403-17.

Firth, A. 2004. Prehistory in the North Sea: Questions from Development-Led Archaeology. In: N. Flemming, ed. Submarine Prehistory of the North Sea: Research Priority and Collaboration with Industry. CBA Research Report 141. 
York: Council for British Archaeology, pp. 89-94.

Fischer, A. 1995. An Entrance to the Mesolithic World Below the Ocean. Status of Ten Years' Work on the Danish Sea Floor. In: A. Fischer, ed. Man and Sea in the Mesolithic. Oxford: Oxbow, pp. 371-84.

Fischer, A. 2004. Submerged Stone Age: Danish Examples and North Sea Potential. In: N.C. Flemming, ed. Submarine Prehistoric Archaeology of the North Sea: Research Priorities and Collaboration with Industry. CBA Research Report 141. York: Council for British Archaeology, pp. 23-36.

Fischer, A. 2011. Stone Age on the Continental Shelf: An Eroding Resource. In: J. Benjamin, C. Pickard \& A. Fischer, eds. 2011. Submerged Prehistory. Oxford: Oxbow, pp. 298-310.

Flemming, N.C. ed. 2004. Submarine Prehistoric Archaeology of the North Sea. Research Priorities and Collaboration with Industry. CBA Research Report 141. York: Council for British Archaeology.

Fredengren, C. 2002. Crannogs: A Study of Peoples' Interaction with Lakes, with Particular Reference to Lough Gara in the North-West of Ireland. Dublin: Wordwell.

Fugazzola Delpino, M.A., D'Eugenio, G. \& Pessina, A. 1993. 'La Marmotta' (Anguilara Sabazia, Roma). Scavi 1979. Un abitato perilcustre di età neolitica. Bullettino di Paletnologia Italiana, 48: 181-342.

Fulford, M., Champion, T.C. \& Long, A. 1997. England's Coastal Heritage: A Survey for English Heritage and the RCHME. English Heritage Archaeological Report 15. London: English Heritage.

Gaspari, A. 2003. Archaeology of the Ljubljanica River (Slovenia): Early Underwater Investigations and Some Current Issues. International Journal of Nautical Archaeology, 32(1): 42-52.

Gaspari, A. ed. 2006. Zalog near Verd. Stone Age Hunters' Camp at the Western Edge of the Ljubljansko Barje. Ljubljana: Institute of Archaeology.

Geddes, G. \& Hale, A. 2010. The Archaeological Landscape of Bute. Edinburgh: Royal Commission on the Ancient and Historic Monuments of Scotland.

Goggin, J. 1960. Underwater Archaeology: Its Nature and Limitations. American Antiquity, 25(3): 348-54.
Hale, A. 2004. Scottish Marine Crannogs. British Archaeological Reports British Series 369. Oxford: Archaeopress.

Hale, A. 2007. Crannogs in South East Scotland. In: J. Barber, C. Clark, M. Cressey, A. Crone, A. Hale, J. Henderson, R. Housley, R. Sands \& A. Sheridan, eds. Archaeology from the Wetlands: Recent Perspectives. Proceedings of the 11th WARP Conference. Edinburgh: Society of Antiquaries of Scotland, pp. 275-80.

Hale, A. \& Sands, R. 2005. Controversy on the Clyde Archaeologists, Fakes and Forgers: The Excavation of Dumbuck Crannog. Edinburgh: RCAHMS.

Harding, D.W. 2007. Crannogs and Island Duns: An Aerial Perspective. In: J. Barber, C. Clark, M. Cressey, A. Crone, A. Hale, J. Henderson, R. Housley, R. Sands \& A. Sheridan, eds. Archaeology from the Wetlands: Recent Perspectives. Proceedings of the 11th WARP Conference. Edinburgh: Society of Antiquaires of Scotland, pp. 267-75.

Henderson, J. 1998. Islets through Time: The Definition, Dating and Distribution of Scottish Crannogs. Oxford Journal of Archaeology, 17(2): 227-44.

Historic Scotland. 2009. Towards a Strategy for Scotland's Marine Historic Environment: Discussion Paper in Association with the Marine Taskforce of the Built Environment Forum of Scotland (BEFS) [online]. Edinburgh: Historic Scotland [accessed 1 January 2010]. Available at: <http://www. historic-scotland.gov.uk/marine-strategy.pdf>

Köninger, J. \& Lübke, C. 2001. Bemerkungen zur vorgeschichtlichen Fischeri im westlichen Bodenseegebiet und in Oberschawen. Nachrichtenblatt Arbeitskreis Untervasserarchäolgie, 8: 67-82.

Lang, A. 1905. The Clyde Mystery. Glasgow: MacLahose.

Larsson, L. 2004. The Mesolithic Period in Southern Scandinavia: With Special Reference to Burials and Cemeteries. In: A. Saville, ed. Mesolithic Scotland and Its Neighbours. Edinburgh: Society of Antiquaries of Scotland, pp. 371-92.

Leineweber, R., Lübke, H., Hellmund, M., Döhle, H.J. \& Klooß, S. 2011. A Late Neolithic fishing fence in Lake Arendsee, Sachsen-Anhalt, Germany. In: J. Benjamin, C. Bonsall, C. Pickard \& A. Fischer, eds. 
Submerged Prehistory. Oxford: Oxbow, pp. 173-85.

Lenihan, D.J. 1983. Rethinking Shipwreck Archaeology: A History of Ideas and Considerations for New Directions. In: R. Gould, ed. Shipwreck Anthropology. Albuquerque: New Mexico Press, pp. 37-64.

Long, A.J. \& Tooley, M.J. 1995. Holocene Sea Level and Crustal Movements in Hampshire and Southeast England. Journal of Coastal Research, 17: 299-310.

Lübke, H., Schmölcke, U. \& Tauber, F. 2011. Mesolithic Hunter-Fishers in a Changing World: A Case Study of Submerged Sites on the Jäckelberg, Wismar Bay, Northeastern Germany. In: J. Benjamin, C. Bonsall, C. Pickard \& A. Fischer, eds. Submerged Prehistory. Oxford: Oxbow, pp. 21-37.

Mackinlay, J. 1859. Notice of Two 'Crannoges' or Pallisaded Islands, in Bute; with Plans. Proceedings of the Society of Antiquaries of Scotland, 3: 43-46.

Masters, P. \& Flemming, N.C. eds. 1983. Quaternary Coastlines and Marine Archaeology. Orlando \& London: Academic Press.

McGrail, S. 2001. Boats of the World: From Stone Age to Medieval Times. Oxford: Oxford University Press.

Miles, D. 2004. Preface. In: N.C. Flemming, ed. Submarine Prehistoric Archaeology of the North Sea. Research Priorities and Collaboration with Industry. CBA Research Report 141. York: Council for British Archaeology, p. xiii.

Momber, G. 2000. Drowned and Deserted: A Submerged Prehistoric Landscape in the Solent, England. International Journal of Nautical Archaeology, 29(1): 86-99.

Momber, G., Tomalin, D., Scaife, R., Satchell, J. \& Gillespie, J. eds. 2011. Mesolithic Occupation at Bouldnor Cliff and the Submerged Prehistoric Landscapes of the Solent. CBA Research Report 164. York: Council for British Archaeology.

Morrison, I. 1985. Landscape with Lake Dwellings. Edinburgh: Edinburgh University Press.

Mowat, R. 1996. The Logboats of Scotland. Oxbow Monograph 68. Oxford: Oxbow.

Muckelroy, K. 1978. Maritime Archaeology. Cambridge: Cambridge University Press.

Muckleroy, K. 1980. Archaeology Under Water: an Atlas of the World's Submerged Sites. McGraw-Hill. ISBN 0070439516.

Munro, R. 1882. Ancient Scottish Lake Dwellings or Crannogs. Edinburgh: David Douglas.
Munro, R. 1905. Archaeology and False Antiquities. London: Methuen.

Nayling, N. \& Manning, S. 2007. Dating the Submerged Forests: Dendrochronology and Radiocarbon 'Wiggle-Match' Dating. In: M. Bell, ed. Prebistoric Coastal Communities: The Archaeology of Western Britain 6000-3000 cal BC. CBA Research Report 149. York: Council for British Archaeology, pp. 90-102.

Needham, S.P. 1988. Selective Deposition in the British Early Bronze Age. World Archaeology, 20(2): 229-48.

O'Neill Henken, H. \& Stelfox, A.W. 1942. Ballinderry Crannog No. 2. Proceedings of the Royal Irish Academy, 47(C): 1-76.

O'Sullivan, A. 1998. The Archaeology of Lake Settlement in Ireland. Discovery Programme Monograph 4. Dublin: The Royal Irish Academy.

O'Sullivan, A. 2001. Foragers, Farmers and Fishers in a Coastal Landscape. Discovery Programme Monograph 5. Dublin: The Royal Irish Academy.

Oxley, I. 2007. Making the Submerged Historic Environment Accessible Beyond the National Heritage Act (2002). In: J. Satchell \& P. Palma, eds. Managing the Marine Cultural Heritage: Defining, Accessing and Managing the Resource. CBA Research Report 153. York: Council for British Archaeology, pp. 87-96.

RCAHMS. 2011. Scotland's Rural Past. Edinburgh: Royal Commission on the Ancient and Historic Monuments of Scotland.

Ruoff, U. 1997. Unterwasserarchäologie im Zürich- und Griefensee. In: H. Schlichtherle, ed. Pfablbauten rund um die Alpen. Stuttgart: Theiss, pp. 42-49.

Satchell, J. \& Palma, P. eds. 2007. Managing the Marine Cultural Heritage: Defining, Accessing and Managing the Resource. CBA Research Report 153. York: Council for British Archaeology.

Schlichtherle, H. 1997. Pfablbauten rund um die Alpen. Stuttgart: Theiss.

Schlichtherle, H. \& Wahlster, B. 1986. Archäologie in Seen und Mooren. Den Pfablbauten auf der Spur. Stuttgart: Theiss.

Smed, P. 1987. Argus Grund - Feltundersøgelser 1984. Fortidsminder og Kulturbistorie, Antikvariske Studier, 8: 125-33.

Szabó, G. 2000. Underwater Archaeological Research in the Carpathian Basin. In: H. von 
Schmettow, A.R. Koldeweij \& J.R. ter Molen, eds. Schutz des Kulturerbes unter Wasser-Veränderungen europäischer Lebenskultur durch Fluß-und Seehandel. Lübstorf: Archäologisches Landesmuseum, pp. 461-66.

Thomas, S. 2010. Community Archaeology in the UK: Recent Findings [online]. York: Council for British Archaeology [accessed 1 April 2011]. Available at: <http://www. britarch.ac.uk/research/community/>

Tizzard, L., Baggaley, P. \& Firth, A. 2011. Seabed Prehistory: Investigating PalaeoLandsurfaces Associated with a Palaeolithic Tool Find, North Sea. In: J. Benjamin, C. Bonsall, C. Pickard \& A. Fischer, eds. Submerged Prehistory. Oxford: Oxbow, pp. 65-73.

Tomalin, D. 1991. Maritime Archaeology as a Coastal Management Issue: a Solent Case Study from the SCOPAC Coast. Proceedings of the 1992 Littlehampton Meeting of the Standing Conference on Problems Associated with the Coastline (SCOPAC). Newport: Isle of Wight County Council, pp. 93-112.

Tomalin, D. 2000. Stress at the Seams: Assessing the Terrestrial and Submerged Archaeological Landscape on the Shore of the Magnus Portus. In: A. Aberg \& C. Lewis, eds. The Rising Tide: Archaeology and Coastal Landscapes. Oxford: Oxbow, pp. 85-98.

Tomalin, D., Momber, G. \& Nayling, N. 2011. The Archaeological Potential of the Solent Submerged Landscapes. In: G. Momber, D. Tomalin, R. Scaife, J. Satchell \& J. Gillespie, eds. Mesolithic Occupation at Bouldnor Cliff and the Submerged Prehistoric Landscapes of the Solent. CBA Research Report 164. York: Council for British Archaeology, pp. 3-14.

UNESCO. 2001. Convention on the Protection of the Underwater Cultural Heritage. United Nations Educational, Scientific and Cultural Organization. Volume 1. Records of the General Conference: 31st Session Paris, 15 October to 3 November 2001. Paris: UNESCO.

Van de Noort, R. \& O'Sullivan, A. 2006. Rethinking Wetland Archaeology. London $\&$ New York: Duckworth.

Weirich, J. 2007. Connecting with the Past: Using Online Tools, Techniques and Partnerships to Explore our Maritime Heritage. In: J. Satchell \& P. Palma, eds. Managing the Marine Cultural Heritage:
Defining, Accessing and Managing the Resource. CBA Research Report 153. York: Council for British Archaeology, pp. 79-86.

Westley, K., Bell, K., Quinn, R. \& Plets, R. 2011. Investigating Submerged Archaeological Landscapes: A Research Strategy Illustrated with Case Studies from Ireland and Newfoundland, Canada. In: J. Benjamin, C. Bonsall, C. Pickard \& A. Fischer, eds. 2011. Submerged Prehistory. Oxford: Oxbow, pp. 65-73.

Wood Martin, W. 1886. The Lake Dwellings of Ireland: Commonly Called Crannogs. Dublin: Hodges Figgis.

York, J. 2002. The Life Cycle of Bronze Age Metalwork from the Thames. Oxford Journal of Archaeology, 21(1): 77-92.

\section{Biographical Notes}

Jonathan Benjamin leads the WA Coastal \& Marine team in its Edinburgh office, where he directs development-led and archaeological research projects. $\mathrm{He}$ is a Fellow in History, Classics and Archaeology at the University of Edinburgh, where he contributes to undergraduate and postgraduate teaching on underwater archaeology, archaeology in practice, and European prehistory. He was the principal editor of Submerged Prehistory (Oxbow Books, 2011).

Address: Wessex Archaeology, Coastal \& Marine, 7/9 North St David Street, Edinburgh EH2 1AW, UK. [email: j. benjamin@wessexarch.co.uk] and University of Edinburgh, School of History, Classics \& Archaeology, Doorway 4 Teviot Place, Edinburgh EH8 9AG, UK. [email: jonathan.benjamin@ed.ac.uk]

Alex Hale is an expert on Scottish Marine Crannogs and has worked for the RCAHMS Survey \& Recording team for over a decade. He is an experienced field 
archaeologist and has conducted extensive work on community engagement, particularly in the west of Scotland. He is co-Chair for the Scottish Archaeology Research Framework's Marine and Maritime Panel.
Address: Royal Commission on the Ancient and Historical Monuments of Scotland, John Sinclair House, 16 Bernard Terrace, Edinburgh EH8 9NX, UK. [email: alex.hale@rcahms.gov.uk]

\section{Préhistoire marine, maritime ou submergée? Contextualisation des archéologies préhistoriques subaquatiques des environnements intérieurs, côtiers et au large}

Les recherches en archéologie préhistorique subaquatique ont gagné un nouvel élan ces dernières années avec un focus particulier sur les régions immergées du plateau continental. Tandis que cet intérêt renouvele se porte surtout sur les côtes et mers modernes, il existe toute une variété de differences entre les archéologies subaquatiques prébistoriques des environnements de terres fermes et des environnements marins allant de questions sur la recherche scientifique à la gestion du patrimoine et aux méthodes pratiques du terrain. Quelques-unes de ces differences résultent de l'endroit, de la fonction et de la période. Malgré ceci, il existe des similarités qui, si elles sont ignorées, risquent de provoquer une marginalisation accrue de l'archéologie des régions submergées par rapport au domaine plus vaste de l'archéologie préhistorique. Une évaluation holistique des régions archéologiques préhistoriques doit inclure les eaux intérieures et les zones côtières ainsi que leurs relations. Les environnements aquatiques, considérés à la fois comme endroits individuels et comme voies d'eau continues et communicantes, sont présentés pour leurs differences et leurs similarités, et des exemples simplifiés de matériel et de legislation sont présentés afin de contextualiser les sites et pratiques sous-marins au sein du vaste domaine de la prébistoire et de l'archéologie subaquatique. Translation by Isabelle Gerges.

Mots cles: archéologie subaquatique, côtier, lacustre, fluvial, estuarien, préhistoire, GrandeBretagne, Écosse

\section{Marine, maritime oder versunkene Vorgeschichte? Zur Kontextualisierung der vorgeschichtlichen Unterwasserarchäologien von Inland-, Küsten- und küstennahen Milieus}

Studien zur Präbistorischen Unterwasserarchäologie sind in den letzten Jahren mit einem besonderen Fokus auf den versunkenen Landschaften des Festlandssockels intensiviert worden. Während sich dieses erneute Interesse vorwiegend auf den modernen Küsten und Seen richtet, gibt es eine Menge Unterschiede zwischen den Unterwasserarchäologien präbistorischer Inland- und mariner Milieus, die von Fragen der wissenschaftlichen Erforschung über denkmalpflegerische Aspekte bis zu praktischen Themen der Feldforschung reichen. Einige dieser Unterschiede rühren aus dem Ort, von der Funktion oder der Periode her. Trotzdem gibt es auch Ähnlichkeiten, die, wenn sie vernachlässigt werden, eine erhöhte Marginalisierung der Archäologie versunkener Landschaften im weiteren Bereich der Prähistorischen Archäologie zeitigen. Eine ganzheitliche Betrachtung vorgeschichtlicher archäologischer Landschaften muss auch Binnengewässer und Küstenzonen sowie deren Beziehungen einschließen. Gewässer, die sowobl als individuelle Orte wie auch als kontinuierliche und verbindende Wasserwege $z u$ betrachten sind, werden hier mit ibren Unterschieden und Gemeinsamkeiten vorgestellt und es werden anhand vereinfachter Beispiele von Material und Gesetzmäßigkeiten gezeigt, um Unterwasserfundplätze und -praktiken im weiteren Feld der Vorgeschichte und der Unterwasserarchäologie zu kontextualisieren. Translation by Heiner Schwarzberg.

Stichworte: unterwasserarchäologie, küstengebiet, seegebiet, flussgebiet, mündungsgebiet, vorgeschichte, Großbritannien, Schottland 